\title{
Static Hyperinflation Is Associated With Decreased Peak Exercise Performance in Children With Cystic Fibrosis
}

\author{
Aleksandar D Sovtic MD MSc, Predrag B Minic MD PhD, Jovan Kosutic MD PhD, \\ Gordana P Markovic-Sovtic MD MSc, and Milan B Gajic PhD
}

\begin{abstract}
BACKGROUND: We evaluated the exercise capacity of children with cystic fibrosis to determine whether ventilatory limitation associated with static hyperinflation is related with decreased exercise capacity, thus predisposing these children to arterial hypoxemia during progressive exercise. METHODS: Thirty-seven children, ages 8-17 years, underwent spirometry, body plethysmography, and cardiopulmonary exercise testing after arterial catheter placement. According to the ratio of residual volume to total lung capacity (RV/TLC), the subjects were categorized as either with (RV/TLC > 30\%) or without static hyperinflation (RV/TLC < 30\%). RESULTS: Children with static hyperinflation showed lower values of maximum load per kilogram (\% predicted) $(P=.01)$, which was aggravated by ventilatory limitation $\left(\mathrm{FEV}_{1}<80 \%\right.$ of predicted, peak oxygen consumption [\% predicted] $<85 \%$, and breathing reserve index $>0.7)$. Subjects with ventilatory limitation had significantly lower oxygen saturation $(P=.04)$ and hypoxemia $(P=.03)$ than did subjects without ventilatory limitation. CONCLUSIONS: In children with cystic fibrosis, static hyperinflation and ventilatory limitation are associated with decrease in exercise performance, oxygen saturation, and $\mathrm{P}_{\mathrm{aO}}$ during maximum cardiopulmonary exercise testing. All children with cystic fibrosis who exhibit static hyperinflation and ventilatory limitation may require $\mathrm{S}_{\mathrm{aO}}$ monitoring during progressive exercise. Key words: blood gas analysis; cystic fibrosis; exercise test; spirometry; whole body plethysmography. [Respir Care 2013;58(2):291-297. (C) 2013 Daedalus Enterprises]
\end{abstract}

\section{Introduction}

Physical activity is an important component of treatment and rehabilitation programs for patients with cystic fibrosis $(\mathrm{CF})$. Physical activity contributes considerably to

\footnotetext{
Drs Sovtic, Minic, and Markovic-Sovtic are affiliated with the Department of Pulmonology; and Dr Kosutic is affiliated with the Department of Cardiology, Mother and Child Health Institute, Belgrade, Serbia. Dr Gajic is affiliated with the Institute for Medical Statistics, Belgrade, Serbia. Drs Minic, Kosutic, and Gajic are also affiliated with the School of Medicine, University of Belgrade, Belgrade, Serbia.
}

The authors have disclosed no conflicts of interest.

Correspondence: Aleksandar D Sovtic MSc, Department of Pulmonology, Mother and Child Health Institute of Serbia, 6 Radoja Dakica Street, 11070 Belgrade, Serbia. E-mail: asovtic@eunet.rs.

DOI: $10.4187 /$ respcare. 01946 improvements in lung function, conditioning, bone density, and quality of life. ${ }^{1-3}$ Peak exercise capacity in CF is influenced by several factors, including age, sex, nutritional status, lung function, skeletal muscle mass, endurance, and respiratory muscle strength. ${ }^{4-7}$ Peak exercise capacity is one of the most reliable markers of prognosis in $\mathrm{CF} .{ }^{8-10}$

Children with moderately severe CF lung disease have impaired lung function, as measured by decreased $\mathrm{FEV}_{1}$. Air flow obstruction and air trapping cause static hyperinflation, quantified by the relationship between residual volume and total lung capacity (RV/TLC). Static hyperinflation may influence peak work rate $\left(\mathrm{W}_{\text {peak }}\right)$ and peak oxygen uptake (peak $\dot{\mathrm{V}}_{\mathrm{O}_{2}}$ ) in adolescents with CF. ${ }^{11}$

An elevated breathing reserve index, defined as the ratio of peak minute ventilation to maximal voluntary ventilation $\left(\dot{\mathrm{V}}_{\mathrm{E}} / \mathrm{MVV}\right)$, may distinguish $\mathrm{CF}$ patients with ventilatory limitation to exercise. ${ }^{12}$ Nevertheless, many patients reach peak $\dot{\mathrm{V}}_{\mathrm{E}}$ exceeding previously measured MVV, 


\section{Static Hyperinflation and Exercise Performance in Children With CF}

so additional parameters are required for predicting ventilatory limitation. ${ }^{3,5}$

Arterial hypoxemia may be an important cause of limited maximal exercise capacity in CF. Hypoxemia results from a combination of factors such as intrapulmonary shunting, ventilation-perfusion mismatch, elevated venous admixture, and alveolar hypoventilation. ${ }^{13}$

The primary objective of this study was to evaluate whether or not children with $\mathrm{CF}$ and ventilatory limitation associated with static hyperinflation are more likely to have decreased exercise capacity than CF patients without ventilatory limitation. We also evaluated whether ventilatory limitation is a predisposing risk factor for development of arterial hypoxemia during incremental exercise.

\section{Methods}

\section{Subjects}

A total of 42 children with $\mathrm{CF}$, ages $8-17$ years, were screened for this study. These subjects constituted practically the entire pediatric CF population in Serbia, capable of performing cardiopulmonary exercise testing (CPET). All subjects were patients of the Mother and Child Health Institute of Serbia. Of the 39 subjects who were enrolled in the study, 37 completed it per protocol. Subjects were diagnosed with $\mathrm{CF}$ according to previously established criteria. ${ }^{14}$ This was a prospective study, conducted from September 2010 until August 2011. The study protocol was approved by the local ethics committee. Subjects and their parents signed informed consents for the investigation.

All participants were clinically stable, without symptoms of pulmonary exacerbation and upper respiratory infection for at least 6 weeks before beginning the study. Height, weight, and body mass index (BMI) were recorded. Measurement of lung function and exercise testing were performed at the same time of the day, on each occasion. Subjects were encouraged to be in their best pharmacologic state: therefore, treatment with bronchodilators was allowed as routine therapy. Although bronchodilator use does not influence peak exercise capacity, it may influence lung volumes. ${ }^{15,16}$ None of the subjects received systemic corticosteroids. One subject received inhaled fluticasone in low doses for associated asthma. In order to achieve the best results, study participants were encouraged to perform a regular course of physiotherapy at home prior to the study.

Subjects were stratified in 2 groups, based on the presence of static hyperinflation, defined as an RV/TLC $>30 \%$. Previously, Sexauer et al, ${ }^{12}$ defined ventilatory limitation during CPET. Similar criteria were used in the current study, including $\mathrm{FEV}_{1}<80 \%$ of predicted; breathing re-

\section{QUICK LOOK}

\section{Current knowledge}

Physical activity contributes considerably to improvements in lung function, conditioning, bone density, and quality of life in patients with cystic fibrosis (CF). Peak exercise capacity in CF is influenced by several factors, including age, sex, nutritional status, lung function, skeletal muscle mass, endurance, and respiratory muscle strength. Peak exercise capacity is one of the most reliable markers of prognosis in $\mathrm{CF}$.

\section{What this paper contributes to our knowledge}

Peak exercise performance is influenced by static hyperinflation. Ventilatory limitation to exercise is an important limiting factor in children with CF. Children with $\mathrm{CF}$ who exhibit static hyperinflation and ventilatory limitation to exercise may require arterial oxygen saturation monitoring during progressive exercise.

serve index at peak effort $>0.7$; and reduced exercise capacity, defined as peak $\dot{\mathrm{V}}_{\mathrm{O}_{2}}<85 \%$.

Before lung function testing and CPET, a catheter was placed either in the brachial or radial artery to draw blood for blood gas analyses, to calculate dead-space ventilation, and to determine lactate concentrations during CPET. All necessary precautions were followed to avoid pain and possible complications during the arterial catheterizations. ${ }^{17}$

\section{Lung Function Testing}

Spirometry and whole body plethysmography were performed before CPET on a regularly calibrated pneumotachography system and using a volume-constant method (MasterLab, Jaeger, Würzburg, Germany). ${ }^{18,19}$ The reference equations used for pulmonary function testing were those of Zapletal et al, and results were compared with predicted values for healthy children matched for age, body height, and sex..20 MVV was calculated for each subject by multiplying the $\mathrm{FEV}_{1}$ value by 35 .

\section{Cardiopulmonary Exercise Test}

Most adolescents included in the study had previously performed CPET as a routine test on annual assessment. Younger children, who had never performed CPET, were familiarized with the equipment and procedures during regular clinical visits before the study began. They were considered ready to undergo a CPET when they clearly expressed their willingness and motivation to do so. Sub- 


\section{Static Hyperinflation and Exercise Performance in Children With CF}

jects performed progressive CPET on an electrically braked cycle ergometer (MasterScreen CPX, Jaeger, Würzburg, Germany), via a ramp protocol to maximum effort. Children were seated comfortably until clinical variables were stable. Work increments were planned individually for each subject, to provide maximal exercise level after approximately $10 \mathrm{~min}$. Determination of maximal effort was based on objective criteria: peak heart rate $>95 \%$ of predicted $(210-$ age $)$ or respiratory exchange ratio $>1$. Subjects were considered to be doing their best to achieve maximal effort if at least one objective criterion was met. Two subjects who did not achieve their maximal effort when performing CPET were excluded from the study. Subjects breathed through a tightly sealed mask that had electronically compensated dead space. The mask was connected to a volume sensor (TripleV, Jaeger/Carefusion, San Diego, California). Expired gas passed through to an attached metabolic cart (Oxycon Pro, CareFusion, San Diego, California) with oxygen and carbon dioxide analyzers. A computer calculated lung volumes, breath-to-breath $\dot{\mathrm{V}}_{\mathrm{E}}, \dot{\mathrm{V}}_{\mathrm{O}_{2}}$, carbon-dioxide production $\left(\dot{\mathrm{V}}_{\mathrm{CO}_{2}}\right)$, and respiratory exchange ratio. Ventilation was expressed as breathing reserve index $\left(\dot{\mathrm{V}}_{\mathrm{E}} / \mathrm{MVV}\right)$. Ventilation relative to $\dot{\mathrm{V}}_{\mathrm{O}_{2}}$ and $\mathrm{CO}_{2}$ output was expressed as ventilatory equivalents for $\mathrm{O}_{2}$ and $\mathrm{CO}_{2}\left(\dot{\mathrm{V}}_{\mathrm{E}} / \dot{\mathrm{V}}_{\mathrm{O}_{2}}\right.$ and $\left.\dot{\mathrm{V}}_{\mathrm{E}} / \dot{\mathrm{V}}_{\mathrm{CO}_{2}}\right)$. Dead-space ventilation was calculated by the Bohr equation, using end-tidal $\mathrm{CO}_{2}$ and $\mathrm{CO}_{2}$ concentration in arterial blood samples. $\mathrm{S}_{\mathrm{pO}_{2}}$ was measured continuously with a reusable sensor placed on the subject's fingertip (3011, Nonin Medical, Plymouth, Minnesota). The anaerobic threshold was determined by increment increase of lactate concentration, or by the V-slope method, depending on the level of elevation of lactate concentration. Samples for blood gas analysis measurement of lactate concentration were obtained every 2 min, and analyzed immediately (ABL 715, Radiometer Medical, Bronshoj, Denmark). Baseline blood pressure was measured at the beginning of the test. Blood pressure was measured every 3 min during the test phase and again at the end of the test. A fully integrated 12-lead electrocardiogram was recorded continuously throughout the test. Immediately after exercise, subjects were asked to score their sense of breathlessness and muscle fatigue at peak exercise, using the Borg scale.

\section{Statistical Analyses}

Statistical analyses were performed at the Institute for Medical Statistics, School of Medicine, Belgrade, Serbia. Data were analyzed using statistics software (SPSS 15, SPSS, Chicago, Illinois) and expressed as mean \pm SD. Differences between groups were analyzed using the Student $t$ test. Dichotomous variables were tested for significance using the chi-square test. $P$ values of $<.05$ were considered to indicate statistical significance. Linear re-
Table 1. Demographic Data

\begin{tabular}{|c|c|c|c|}
\hline & $\begin{array}{c}\text { Static } \\
\text { Hyperinflation } \\
(\mathrm{RV} / \mathrm{TLC}>30 \%) \\
(n=25)\end{array}$ & $\begin{array}{c}\text { No Static } \\
\text { Hyperinflation } \\
(\mathrm{RV} / \mathrm{TLC}<30 \%) \\
(n=12)\end{array}$ & Total \\
\hline Age, mean $\pm \mathrm{SD}, \mathrm{y}$ & $13.02 \pm 3.23$ & $10.95 \pm 2.86$ & $11.98 \pm 3.04$ \\
\hline Male, no. & 13 & 6 & 19 \\
\hline Female, no. & 12 & 6 & 18 \\
\hline $\begin{array}{l}\text { Body mass index, } \\
\text { mean } \pm \mathrm{SD}, \mathrm{kg} / \mathrm{m}^{2}\end{array}$ & $17.22 \pm 2.76$ & $17.37 \pm 4.43$ & $17.7 \pm 3.33$ \\
\hline $\begin{array}{l}\mathrm{FEV}_{1} \text {, mean } \pm \mathrm{SD} \\
\% \text { predicted }\end{array}$ & $74.98 \pm 26.68$ & $105.28 \pm 12.47$ & $84.81 \pm 26.99 *$ \\
\hline
\end{tabular}

gression was used to evaluate correlations between parameters. Sample size estimation was performed according to data obtained after evaluation of the results of the first 15 subjects. Response within each subject group (with or without static hyperinflation) was normally distributed, with a standard deviation of 0.2 . If the true difference in the experimental and control means of breathing reserve index was 0.25 , we would be able to reject the null hypothesis that the population means of the experimental and control groups were equal with a probability (power) of 0.938 . The type 1 error probability associated with this test of this null hypothesis was .05 (2-sided).

\section{Results}

Data collected from 37 children with CF (18 male, 19 female) were included in this analysis. In 28 subjects, CPET was terminated due to dyspnea and associated leg discomfort. In 9 subjects the exercise performance was limited by dyspnea only. The mean subject age was $11.98 \pm 3.04$ years (range 8-17 y). Subjects were divided into 2 groups based on the presence or absence of static hyperinflation (Table 1).

There were no statistically significant differences in age, sex, and mean BMI between subjects with and without static hyperinflation. The mean $\mathrm{FEV}_{1}$ of all study participants was $84.8 \%$. Subjects with static hyperinflation had significantly lower $\mathrm{FEV}_{1}$ values $(P=.001)$.

CPET measurement showed that the static hyperinflation group had lower mean $\mathrm{W}_{\text {peak }} / \mathrm{kg}(\%$ predicted $)(P=.01)$ values, but there were no significant differences in peak $\dot{\mathrm{V}}_{\mathrm{O}_{2}} / \mathrm{kg}$ between groups. The peak $\dot{\mathrm{V}}_{\mathrm{O}_{2}}$ per unit work rate was not significantly greater in subjects with static hyperinflation than in those without static hyperinflation $(P=.52) . \dot{\mathrm{V}}_{\mathrm{E}} / \dot{\mathrm{V}}_{\mathrm{CO}_{2}}$ and $\dot{\mathrm{V}}_{\mathrm{E}} / \dot{\mathrm{V}}_{\mathrm{O}_{2}}$ were significantly lower in the group without static hyperinflation at the anaerobic threshold $(P=.03, P=.003)$, but not at $\mathrm{W}_{\text {peak }}$. There were no significant differences in $\mathrm{P}_{\mathrm{aO}_{2}}, \mathrm{~S}_{\mathrm{aO}}$, and lactate 


\section{Static Hyperinflation and Exercise Performance in Children With CF}

Table 2. Results of Cardiopulmonary Exercise Testing in the Static Hyperinflation and No Static Hyperinflation Groups

\begin{tabular}{|c|c|c|c|}
\hline & $\begin{array}{c}\text { Static } \\
\text { Hyperinflation }\end{array}$ & $\begin{array}{c}\text { No Static } \\
\text { Hyperinflation }\end{array}$ & $P$ \\
\hline $\mathrm{W}_{\text {peak }} / \mathrm{kg}, \%$ predicted & $78.56 \pm 12.51$ & $93 \pm 19.78$ & .01 \\
\hline Peak $\dot{\mathrm{V}}_{\mathrm{O}_{2}} / \mathrm{kg}, \mathrm{mL} / \mathrm{min} / \mathrm{kg}$ & $34.6 \pm 7.15$ & $36.07 \pm 4.5$ & .52 \\
\hline Peak $\dot{\mathrm{V}}_{\mathrm{O}_{2}} / \mathrm{kg}, \%$ predicted & $84.52 \pm 15.87$ & $90.00 \pm 13.46$ & .31 \\
\hline $\begin{array}{l}\dot{\mathrm{V}}_{\mathrm{E}} / \mathrm{V}_{\mathrm{CO}_{2}} \text { at anaerobic } \\
\text { threshold }\end{array}$ & $34.82 \pm 4.72$ & $31.08 \pm 4.47$ & .03 \\
\hline$\dot{\mathrm{V}}_{\mathrm{E}} / \mathrm{V}_{\mathrm{CO}_{2}}$ at $\mathrm{W}_{\text {peak }}$ & $33.03 \pm 3.70$ & $32.32 \pm 3.90$ & .59 \\
\hline $\begin{array}{l}\dot{\mathrm{V}}_{\mathrm{E}} / \dot{\mathrm{V}}_{\mathrm{O}_{2}} \text { at anaerobic } \\
\text { threshold }\end{array}$ & $31.89 \pm 3.76$ & $27.60 \pm 4.15$ & .003 \\
\hline$\dot{\mathrm{V}}_{\mathrm{E}} / \dot{\mathrm{V}}_{\mathrm{O}_{2}}$ at $\mathrm{W}_{\text {peak }}$ & $35.76 \pm 4.73$ & $36.41 \pm 5.59$ & .71 \\
\hline $\mathrm{V}_{\mathrm{D}} / \mathrm{V}_{\mathrm{T}}$ at rest $(\%)$ & $38.4 \pm 5.2$ & $34.1 \pm 7.2$ & .03 \\
\hline $\mathrm{V}_{\mathrm{D}} / \mathrm{V}_{\mathrm{T}}$ at $\mathrm{W}_{\text {peak }}(\%)$ & $41.6 \pm 5.1$ & $39.4 \pm 9.3$ & .47 \\
\hline $\begin{array}{l}\text { Breathing reserve index } \\
\text { at } W_{\text {peak }}\end{array}$ & $0.85 \pm 0.24$ & $0.61 \pm 0.09$ & .002 \\
\hline $\mathrm{P}_{\mathrm{aO}_{2}}$ at rest, $\mathrm{mm} \mathrm{Hg}$ & $120 \pm 20$ & $105 \pm 19$ & .03 \\
\hline $\mathrm{P}_{\mathrm{aO}_{2}}$ at $\mathrm{W}_{\text {peak }}, \mathrm{mm} \mathrm{Hg}$ & $109 \pm 26$ & $120 \pm 14$ & .20 \\
\hline $\mathrm{S}_{\mathrm{aO}_{2}}$ at rest $(\%)$ & $96.60 \pm 2.14$ & $97.67 \pm 0.89$ & .11 \\
\hline $\mathrm{S}_{\mathrm{aO}_{2}}$ at $\mathrm{W}_{\text {peak }}(\%)$ & $92.36 \pm 5.12$ & $94.00 \pm 2.63$ & .30 \\
\hline Lactate at $\mathrm{W}_{\text {peak }}, \mathrm{mmol} / \mathrm{L}$ & $4.56 \pm 1.62$ & $4.65 \pm 1.42$ & .89 \\
\hline $\begin{array}{l}\text { Respiratory exchange } \\
\text { ratio at } \mathrm{W}_{\text {peak }}\end{array}$ & $1.10 \pm 0.13$ & $1.14 \pm 0.11$ & .80 \\
\hline $\begin{array}{l}\text { Borg dyspnea score at } \\
\mathrm{W}_{\text {peak }}\end{array}$ & $7.2 \pm 2.95$ & $6.4 \pm 1.1$ & .10 \\
\hline $\begin{array}{l}\text { Borg muscle fatigue } \\
\text { score at } \mathrm{W}_{\text {peak }}\end{array}$ & $9 \pm 0$ & $8.6 \pm 0.75$ & .38 \\
\hline \multicolumn{4}{|c|}{$\begin{array}{l}\text { Values are mean } \pm \mathrm{SD} \text {. } \\
\mathrm{W}_{\text {peak }} / \mathrm{kg}=\text { maximal load } / \mathrm{kg}, \% \text { predicted } \\
P_{\text {eak }} \dot{\mathrm{V}}_{\mathrm{O}_{2}} / \mathrm{kg}=\text { maximal oxygen consumption } / \mathrm{kg} \\
\dot{\mathrm{V}}_{\mathrm{E}} / \mathrm{V}_{\mathrm{CO}_{2}}=\text { minute ventilation } / \text { carbon dioxide output (ventilatory equivalent for carbon } \\
\text { dioxide) } \\
\dot{\mathrm{V}}_{\mathrm{E}} / \dot{\mathrm{V}}_{\mathrm{O}_{2}}=\text { minute ventilation } / \text { oxygen consumption (ventilator equivalent for oxygen) } \\
\mathrm{V}_{\mathrm{D}}=\text { dead space } \\
\mathrm{V}_{\mathrm{T}}=\text { tidal volume }\end{array}$} \\
\hline
\end{tabular}

concentration at $\mathrm{W}_{\text {peak }}$ between groups (Table 2). For 9 subjects the anaerobic threshold was determined using the $\mathrm{V}$-slope method, because there were no appropriate increases in lactate concentration. In 28 others the lactate threshold was used.

\section{Ventilatory Limitation During CPET}

Five subjects in the static hyperinflation group (20\%) had ventilatory limitation. None of the subjects in the nothyperinflated group had ventilatory limitation (Table 3). The Fisher exact test showed that static hyperinflation and ventilatory limitation were not associated $(P=.12)$.

$\mathrm{W}_{\text {peak }} / \mathrm{kg}$ (\% predicted) and peak $\dot{\mathrm{V}}_{\mathrm{O}_{2}} / \mathrm{kg}$ were significantly lower in subjects with static hyperinflation and ventilatory limitation than in subjects without ventilatory limitation $(P<.001, P=.02)$. At rest, $\mathrm{P}_{\mathrm{aO}_{2}}$ values were lower in subjects with ventilatory limitation than in subjects without ventilatory limitation $(P=.048)$. At peak
Table 3. Subjects With Static Hyperinflation and With or Without Ventilatory Limitation

\begin{tabular}{|c|c|c|c|}
\hline & $\begin{array}{l}\text { Static } \\
\text { Hyperinflation } \\
\text { and } \\
\text { Ventilatory } \\
\text { Limitation }\end{array}$ & $\begin{array}{l}\text { Static } \\
\text { Hyperinflation } \\
\text { and No } \\
\text { Ventilatory } \\
\text { Limitation }\end{array}$ & $P$ \\
\hline $\mathrm{W}_{\text {peak }} / \mathrm{kg}, \%$ predicted & $62.60 \pm 7.96$ & $82.55 \pm 10.03$ & -.00 \\
\hline Peak $\dot{\mathrm{V}}_{\mathrm{O}_{2}} / \mathrm{kg}, \mathrm{mL} / \mathrm{min} / \mathrm{kg}$ & $28.02 \pm 5.37$ & $36.24 \pm 6.66$ & .02 \\
\hline Peak $\dot{\mathrm{V}}_{\mathrm{O}_{2}} / \mathrm{kg}, \%$ predicted & $64.80 \pm 14.24$ & $89.66 \pm 12.44$ & $<.001$ \\
\hline $\begin{array}{l}\dot{\mathrm{V}}_{\mathrm{E}} / \mathrm{V}_{\mathrm{CO}_{2}} \text { at anaerobic } \\
\text { threshold }\end{array}$ & $19.02 \pm 5.06$ & $23.40 \pm 7.37$ & .10 \\
\hline$\dot{\mathrm{V}}_{\mathrm{E}} / \mathrm{V}_{\mathrm{CO}_{2}}$ at $\mathrm{W}_{\text {peak }}$ & $34.50 \pm 2.72$ & $32.66 \pm 3.88$ & .33 \\
\hline $\begin{array}{l}\dot{\mathrm{V}}_{\mathrm{E}} / \dot{\mathrm{V}}_{\mathrm{O}_{2}} \text { at anaerobic } \\
\text { threshold }\end{array}$ & $33.59 \pm 1.45$ & $31.47 \pm 4.06$ & .27 \\
\hline$\dot{\mathrm{V}}_{\mathrm{E}} / \dot{\mathrm{V}}_{\mathrm{O}_{2}}$ at $\mathrm{W}_{\text {peak }}$ & $36.99 \pm 6.53$ & $35.46 \pm 4.33$ & .53 \\
\hline $\mathrm{V}_{\mathrm{D}} / \mathrm{V}_{\mathrm{T}}$ at rest $(\%)$ & $38.2 \pm 3.0$ & $38.4 \pm 6.1$ & .81 \\
\hline $\mathrm{V}_{\mathrm{D}} / \mathrm{V}_{\mathrm{T}}$ at $\mathrm{W}_{\text {peak }}(\%)$ & $42.8 \pm 4.3$ & $40.3 \pm 1.2$ & .45 \\
\hline $\begin{array}{l}\text { Breathing reserve index at } \\
\mathrm{W}_{\text {peak }}\end{array}$ & $1.08 \pm 0.19$ & $0.80 \pm 0.22$ & .01 \\
\hline $\mathrm{P}_{\mathrm{aO}_{2}}$ at rest, $\mathrm{mm} \mathrm{Hg}$ & $90 \pm 18$ & $109 \pm 18$ & .04 \\
\hline $\mathrm{P}_{\mathrm{aO}_{2}}$ at $\mathrm{W}_{\text {peak }}, \mathrm{mm} \mathrm{Hg}$ & $87 \pm 23$ & $115 \pm 24$ & .03 \\
\hline $\mathrm{S}_{\mathrm{aO}_{2}}$ at rest $(\%)$ & $94.80 \pm 3.56$ & $97.05 \pm 1.43$ & .03 \\
\hline $\mathrm{S}_{\mathrm{aO}_{2}}$ at $\mathrm{W}_{\text {peak }}(\%)$ & $88.20 \pm 5.45$ & $93.4 \pm 4.60$ & .04 \\
\hline Lactate at $\mathrm{W}_{\text {peak }}(\mathrm{mmol} / \mathrm{L})$ & $4.56 \pm 2.26$ & $4.57 \pm 1.50$ & $>.99$ \\
\hline $\begin{array}{l}\text { Respiratory exchange ratio } \\
\text { at } W_{\text {peak }}\end{array}$ & $1.07 \pm 0.13$ & $1.10 \pm 0.09$ & .82 \\
\hline Borg dyspnea score & $7.20 \pm 2.95$ & $6.40 \pm 1.10$ & .32 \\
\hline Borg muscle fatigue score & $9 \pm 0$ & $8.60 \pm 0.75$ & .26 \\
\hline \multicolumn{4}{|c|}{$\begin{array}{l}\text { Values are mean } \pm \mathrm{SD} \text {. } \\
\text { Peak } \dot{\mathrm{V}}_{\mathrm{O}_{2}} / \mathrm{kg}=\text { maximal oxygen consumption } / \mathrm{kg} \\
\dot{\mathrm{V}}_{\mathrm{E}} / \mathrm{V}_{\mathrm{CO}_{2}}=\text { minute ventilation/carbon dioxide output (ventilatory equivalent for carbon } \\
\text { dioxide) } \\
\dot{\mathrm{V}}_{\mathrm{E}} / \mathrm{V}_{\mathrm{O}_{2}}=\text { minute ventilation/oxygen consumption (ventilator equivalent for oxygen) } \\
\mathrm{V}_{\mathrm{D}}=\text { dead space } \\
\mathrm{V}_{\mathrm{T}}=\text { tidal volume }\end{array}$} \\
\hline
\end{tabular}

exercise these differences in $\mathrm{P}_{\mathrm{aO}_{2}}$ became more pronounced $(P=.03)$. The Student $t$ test for paired samples showed that subjects with ventilatory limitation had significantly lower $\mathrm{S}_{\mathrm{aO}_{2}}$ at $\mathrm{W}_{\text {peak }}$ than at rest $(P=.009)$. A similar relationship was observed in subjects without ventilatory limitation $(P<.001)$. Only subjects with ventilatory limitation had clinically important decreases of $\mathrm{S}_{\mathrm{aO}_{2}}$ below $90 \%$.

\section{Association Between Variables}

Single linear regression showed that RV/TLC (\%) and $\mathrm{FEV}_{1}(\%)$ were independently statistically significant predictors of $\mathrm{W}_{\text {peak }} / \mathrm{kg}$ : RV/TLC $\mathrm{R}=-0.43, \mathrm{~B}=-0.145$, $\beta=-0.437, P=.007 ; \mathrm{FEV}_{1} \mathrm{R}=0.46, \mathrm{~B}=0.285$, $\beta=0.468, P=.003$. However, stepwise multiple linear regressions showed that $\mathrm{FEV}_{1}$ was a more powerful predictor of $\mathrm{W}_{\text {peak }} / \mathrm{kg}$. 


\section{Static Hyperinflation and Exercise Performance in Children With CF}
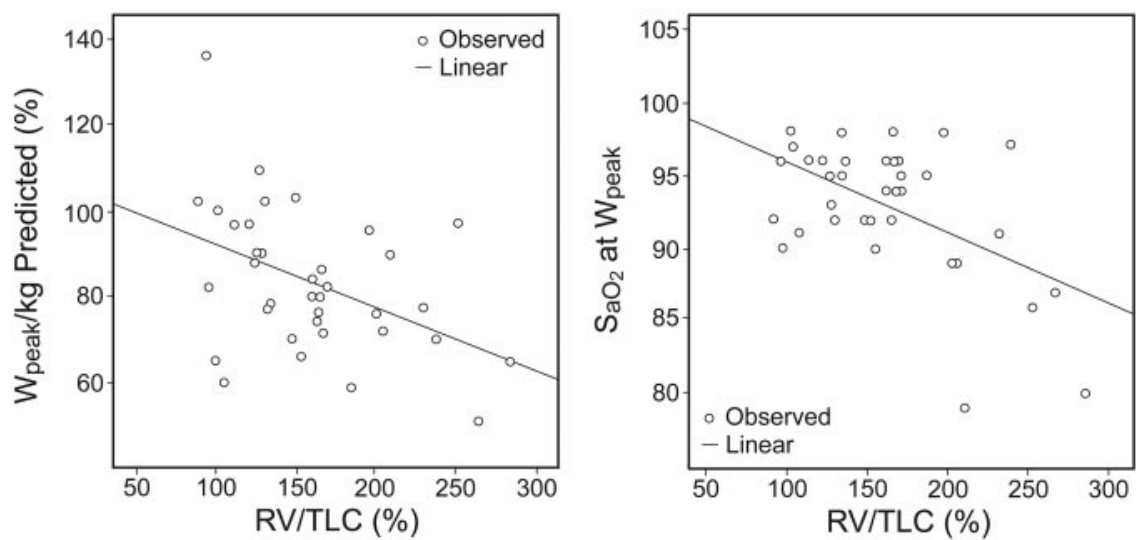

Figure. Association between the ratio of residual volume (RV) and total lung capacity (TLC), exercise capacity, and arterial oxygen saturation $\left(\mathrm{S}_{\mathrm{aO}_{2}}\right)$ at peak work $\left(\mathrm{W}_{\text {peak }}\right)$.

Table 4. Correlation Between Variables

\begin{tabular}{|c|c|c|c|c|c|}
\hline & $\mathrm{P}_{\mathrm{aO}_{2}}$ at $\mathrm{W}_{\text {peak }}$ & $\mathrm{S}_{\mathrm{aO}_{2}}$ at $\mathrm{W}_{\text {peak }}$ & $\begin{array}{l}\mathrm{W}_{\text {peak }} / \mathrm{kg}, \\
\% \text { predicted }\end{array}$ & Peak $\dot{\mathrm{V}}_{\mathrm{O}_{2}} / \mathrm{kg}$ & $\dot{\mathrm{V}}_{\mathrm{E}} / \mathrm{V}_{\mathrm{CO}_{2}}$ at $\mathrm{W}_{\text {peak }}$ \\
\hline RV/TLC & $-0.59^{*}$ & $-0.53 *$ & $-0.44^{*}$ & $-0.39 \dagger$ & 0.20 \\
\hline $\mathrm{FEV}_{1}(\%)$ & $0.55^{*}$ & $0.58 *$ & $0.47^{*}$ & $0.44^{*}$ & -0.12 \\
\hline Body mass index & 0.17 & 0.06 & -0.24 & -0.26 & $-0.51^{*}$ \\
\hline $\mathrm{P}_{\mathrm{aO}_{2}}$ at rest & $0.49^{*}$ & 0.29 & 0.22 & 0.20 & -0.08 \\
\hline Borg dyspnea score & $-0.42 \dagger$ & -0.29 & 0.04 & -0.10 & $0.50^{*}$ \\
\hline \multicolumn{6}{|c|}{$\begin{array}{l}\text { Values are Pearson correlation coefficients. } \\
* P<.001 . \\
\dagger P<.05 \text {. } \\
\mathrm{W}_{\text {peak }}=\text { maximal work load } \\
\mathrm{S}_{\mathrm{aO}}=\text { arterial oxygen saturation } \\
\mathrm{Peak}_{\mathrm{V}_{\mathrm{O}_{2}} / \mathrm{kg}=\text { maximal oxygen consumption } / \mathrm{kg}} \\
\mathrm{V}_{\mathrm{E}} / \mathrm{V}_{\mathrm{C}_{2}}=\text { minute ventilation } / \text { carbon dioxide output (ventilatory equivalent for carbon dioxide) } \\
\mathrm{RV} / \mathrm{TLC}=\text { residual volume/total lung capacity }\end{array}$} \\
\hline
\end{tabular}

The Figure shows the association between RV/TLC, exercise capacity, and $\mathrm{S}_{\mathrm{aO}_{2}}$ at $\mathrm{W}_{\text {peak }}$.

The multivariate general linear model showed that RV/TLC can predict desaturation and hypoxemia $(P<$ $.001, \mathrm{Eta}^{2}=0.392$ ). Pearson correlation analysis showed that the increase in RV/TLC (\%) was not significantly dependent on age $\left(\mathrm{R}^{2}=0.097, P=.06\right)$. Pearson correlations of RV/TLC, $\mathrm{FEV}_{1}$, and other variables with parameters obtained from exercise testing are displayed in Table 4.

\section{Discussion}

Our data show that static hyperinflation is associated with decreased exercise capacity in children with CF. We demonstrated that static hyperinflation ( RV/TLC $>30 \%$ ), similar to $\mathrm{FEV}_{1}(\%)$, is a strong predictor of $\mathrm{W}_{\text {peak }} / \mathrm{kg}$ in children with $\mathrm{CF}$. Werkman et al, ${ }^{11}$ presented comparable results in adolescents with $\mathrm{CF}$. Previous research showed that $\mathrm{FEV}_{1}$ correlates with exercise capacity in patients with CF.7,8 Progression of static hyperinflation in these patients may be the first sign of deterioration of lung func- tion, before deceleration of $\mathrm{FEV}_{1}$ appears. ${ }^{21}$ Young children in whom respiratory dysfunction and static hyperinflation occur earlier and with greater severity are more likely to follow a more rapid decline in pulmonary function. ${ }^{22}$

Although all subjects with ventilatory limitation during exercise had static hyperinflation, RV/TLC was not a predictor of ventilatory limitation. An equivalent predictive model was shown for adult CF patients. ${ }^{12}$

One of the parameters used in our study to describe ventilatory limitation (breathing reserve index $\mathrm{W}_{\text {peak }}>0.7$ ) is probably higher in younger children. ${ }^{11}$ Estimation of the anaerobic threshold by the V-slope method, which was used for some subjects, may have influenced breathing reserve index values at the anaerobic threshold, but not at $\mathrm{W}_{\text {peak }}{ }^{23}$ Our results show that breathing reserve index at $\mathrm{W}_{\text {peak }}$ is a useful indicator of ventilatory limitation, even in younger children.

In obstructive lung diseases such as CF there is a progressive increase of dead-space volume during exercise, accompanied by increases in dynamic hyperinflation and 


\section{Static Hyperinflation and Exercise Performance in Children With CF}

total ventilation. ${ }^{24,25}$ We showed that there was an increase in dead-space ventilation at rest in both groups, with significantly higher values observed in the static hyperinflation group. Interestingly, the progressive increase in $\mathrm{V}_{\mathrm{D}} / \mathrm{V}_{\mathrm{T}}$ did not result in significantly higher values in the static hyperinflation group. Similar results associated with $\mathrm{V}_{\mathrm{D}} / \mathrm{V}_{\mathrm{T}}$ in the ventilatory limitation and non-ventilatory limitation groups at rest and at $\mathrm{W}_{\text {peak }}$ indicate that ventilatory limitation is not appropriate for assessment of dead-space ventilation. It was observed that hyperinflation has a mechanically disadvantageous role on the performance of the diaphragm, which becomes flatter and shorter. Hyperinflation causes reduction in the apposition zone of the diaphragm, and a smaller rise in abdominal pressure, leading to its dysfunction. ${ }^{26}$ Dynamic hyperinflation is best reflected by changes in inspiratory capacity, which was not measured in this study. ${ }^{19}$

Vogiatzis et $\mathrm{al}^{27}$ showed that patients with severe COPD exhibit 2 patterns of dynamic hyperinflation during progressive exercise test: early and late. During exercise, in patients with $\mathrm{CF}$ and COPD there are progressive increases of end-expiratory chest wall and rib cage volumes, due to expiratory flow limitation. ${ }^{28}$ Some patients with obstructive lung disease do not reach expiratory flow limitation up to two thirds of $\mathrm{W}_{\text {peak }} \cdot{ }^{27}$ Increase of $\dot{\mathrm{V}}_{\mathrm{E}}$ and progressive increase of end-expiratory lung volumes have negative influence on breathing reserve index in estimation of ventilatory limitation in patients with air-flow obstruction and dynamic hyperinflation during progressive CPET. Expiratory flow limitation is a cause of increased $\dot{\mathrm{V}}_{\mathrm{E}} / \dot{\mathrm{V}}_{\mathrm{CO}_{2}}$, limiting exercise capacity in patients with COPD. ${ }^{29}$ Dynamic hyperinflation may affect the predictive accuracy of $\dot{\mathrm{V}}_{\mathrm{E}} / \dot{\mathrm{V}}_{\mathrm{CO}_{2}}$ on ventilatory efficacy above the respiratory compensation point. ${ }^{30,31} \mathrm{We}$ demonstrated that there was a difference between the groups according to $\dot{\mathrm{V}}_{\mathrm{E}} / \dot{\mathrm{V}}_{\mathrm{CO}_{2}}$ at the anaerobic threshold, but not at $\mathrm{W}_{\text {peak }}$, in accordance with previous data. Our results indicate that $\dot{\mathrm{V}}_{\mathrm{E}} / \dot{\mathrm{V}}_{\mathrm{CO}_{2}}$ should be interpreted with caution for assessment of ventilatory efficacy in children with CF.

In our study, peak $\dot{\mathrm{V}}_{\mathrm{O}_{2}}$ was significantly lower in subjects with ventilatory limitation, because peak $\dot{\mathrm{V}}_{\mathrm{O}_{2}}$ was used as one of the parameters to describe ventilatory limitation. Conversely, at $\mathrm{W}_{\text {peak }}$, lactate concentrations in subjects with ventilatory limitation were similar to those in subjects without ventilatory limitation. Lactate concentration positively correlates with peak $\dot{\mathrm{V}}_{\mathrm{O}_{2}}$ in adult patients with $\mathrm{CF} .{ }^{32}$ Moderate elevation in lactate concentration at $\mathrm{W}_{\text {peak }}$ and high Borg muscle fatigue scores in all patients suggest relatively good skeletal muscle conditioning. In the presence of good muscle conditioning, low peak $\dot{\mathrm{V}}_{\mathrm{O}_{2}}$ in static hyperinflation subjects may be primarily due to ventilatory reasons. This is confirmed by the greater peak $\dot{\mathrm{V}}_{\mathrm{O}_{2}}$ per unit work rate in static hyperinflation subjects, which may also be caused by cardiovascular and possibly metabolic factors.

Peak $\dot{\mathrm{V}}_{\mathrm{O}_{2}}$ is one of the best predictive markers of prognosis and mortality in CF. $8,10,33$ With this in mind, Gruet et $\mathrm{al}^{34}$ proposed a model for $\mathrm{CF}$ patients who are unable to perform the maximal exercise test. Gruet et al showed that the oxygen uptake efficiency slope is a useful submaximal parameter that correlates with values at $\mathrm{W}_{\text {peak. }}$. Further studies are necessary to validate these valuable data in young children; motivating these children to achieve their best results during CPET may be a challenge.

Exercise-induced hypoxemia and clinically important oxygen desaturation $\left(\mathrm{S}_{\mathrm{aO}_{2}}<90 \%\right)$ at $\mathrm{W}_{\text {peak }}$ were demonstrated only in subjects with static hyperinflation and ventilatory limitation. We concluded that ventilatory limitation may be a predisposing factor for developing oxygen desaturation at peak exercise. McKone et al ${ }^{13}$ showed that adding dead-space volume and supplemental oxygen can increase peak exercise ventilation and improve maximal exercise capacity in adult $\mathrm{CF}$ patients. It is unclear whether or not oxygen supplementation can be advised as a therapeutic measure in training and rehabilitation protocols for children with CF and ventilatory limitation on CPET. The role of oxygen supplementation in improvement of submaximal exercise capacity among adults with $\mathrm{CF}$ has been documented, but further investigations are necessary to completely understand the influence of oxygen supplementation during exercise in children. ${ }^{35,36}$

Similar values of BMI within groups in our study showed their comparability in nutritional status. Our data showed that BMI was negatively correlated with $\mathrm{W}_{\text {peak }}$, but that the correlation was not significant. Previous reports suggest that malnutrition plays an important role in determining exercise capacity in CF. 5,6 We believe that nutritional status should be evaluated more precisely than was done in our study (lean body mass and weight for height), in order to draw reliable conclusions on its impact on exercise capacity. The lack of significance in correlation between BMI with $\mathrm{W}_{\text {peak }}$ may be explained by the relative homogeneity of this small group of subjects. Potential limitations are difficulties in accommodation to the cycle ergometer for CPET-naive children, and their expression of muscle fatigue using the Borg scale. In addition, estimation of arterial blood gases concentration is invasive. It would be difficult to justify arterial line placement for the purpose of routine clinical assessment. We propose that it should be reserved only for the purpose of scientific research.

\section{Conclusions}

In conclusion, peak exercise performance is influenced by static hyperinflation, and ventilatory limitation is a significant limiting factor in children with $\mathrm{CF}$. In clinical 


\section{Static Hyperinflation and Exercise Performance in Children With CF}

practice it is unlikely that children with $\mathrm{CF}$ force themselves to maximal effort during exercise sessions. Nevertheless, we would like to emphasize that all children with CF who exhibit static hyperinflation and ventilatory limitation may require $\mathrm{S}_{\mathrm{aO}}$ monitoring during progressive exercise. Given these findings, further study of the influence of hyperinflation on exercise capacity in children with CF should focus on improvements in ventilatory limitation, which is a part of the natural course of the disease.

\section{ACKNOWLEDGMENTS}

The authors would like to express their appreciation to all children with $\mathrm{CF}$ who have been treated at the Mother and Child Health Institute of Serbia, and their parents, who have shown willingness and motivation to participate in numerous clinical research projects over the last decade.

\section{REFERENCES}

1. Paranjape SM, Barnes LA, Carson KA, von Berg K, Loosen H, Mogayzel PJ. Exercise improves lung function and habitual activity in children with cystic fibrosis. J Cyst Fibros 2012;11(1):18-23.

2. Hind K, Truscott JG, Conway SP. Exercise during childhood and adolescence: a prophylaxis against cystic fibrosis-related low bone mineral density? Exercise for bone health in children with cystic fibrosis. J Cyst Fibros 2008;7(4):270-276.

3. Moorcroft AJ, Dodd ME, Webb AK. Exercise limitations and training for patients with cystic fibrosis. Disabil Rehabil 1998;20(6-7): 247-253.

4. Troosters T, Langer D, Vrijsen B, Segers J, Wouters K, Janssens W, et al. Skeletal muscle weakness, exercise tolerance and physical activity in adults with cystic fibrosis. Eur Respir J 2009;33(1):99-106.

5. Marcotte JE, Grisdale RK, Levison H, Coates AL, Canny GJ. Multiple factors limit exercise capacity in cystic fibrosis. Pediatr Pulmonol 1986;2(5):274-281.

6. Marcotte JE, Canny GJ, Grisdale R, Desmond K, Corey M, Zinman $\mathrm{R}$, et al. Effect of nutritional status on exercise performance in advanced cystic fibrosis. Chest 1986;90(3):375-379.

7. Pianosi P, LeBlanc J, Almudevar A. Relationship between $\mathrm{FEV}_{1}$ and peak oxygen uptake in children with cystic fibrosis. Pediatr Pulmonol 2005;40(4):324-329.

8. Nixon PA, Orenstein DM, Kelsey SF, Doershuk CF. The prognostic value of exercise testing in patients with cystic fibrosis. $\mathrm{N}$ Engl J Med 1992;327(25):1785-1788.

9. Moorcroft AJ, Dodd ME, Webb AK. Exercise testing and prognosis in adult cystic fibrosis. Thorax 1997;52(3):291-293.

10. Pianosi P, LeBlanc J, Almudevar A. Peak oxygen uptake and mortality in children with cystic fibrosis. Thorax 2005;60(1):50-54.

11. Werkman MS, Hulzebos HJ, Arets HG, van der Net J, Helders PJ, Takken T. Is static hyperinflation a limiting factor during exercise in adolescents with cystic fibrosis. Pediatr Pulmonol 2011;46(2): 119-124.

12. Sexauer WP, Cheng HK, Fiel SB. Utility of the breathing reserve index at the anaerobic threshold in determing ventilatory-limited exercise in adult cystic fibrosis. Chest 2003;124(4):1469-1475.

13. McKone EF, Barry SC, Fitzgerald MX, Gallagher CG. Role of arterial hypoxemia and pulmonary mechanics in exercise limitation in adults with cystic fibrosis. J Appl Physiol 2005;99(3):1012-1018.

14. Rosenstein BJ, Cutting GR. The diagnosis of cystic fibrosis: a consensus statement. Cystic Fibrosis Foundation consensus panel. J Pediatr 1998;132(4):589-595.
15. Dodd JD, Barry SC, Daly LE, Gallagher CG. Inhaled beta-agonists improve lung function but not maximal exercise capacity in cystic fibrosis. J Cyst Fibros 2005;4(2):101-105.

16. Serisier DJ, Coates AD, Bowler SD. Effect of albuterol on maximal exercise capacity in cystic fibrosis. Chest 2007;131(4):1181-1187.

17. Tegtmeyer K, Brady G, Lai S, Hodo R, Braner D. Placement of an arterial line. N Engl J Med 2006;354(15):e13.

18. Miller MR, Hankinson J, Brusasco V, Burgos F, Casaburi R, Coates A, et al; ATS/ERS Task Force. Standardization of spirometry. Eur Respir J 2005;26(2):319-338.

19. Gibson G. Tests of mechanical function. In: Clinical tests of pulmonary function. London: Chapman \& Hall; 1996:13-53.

20. Zapletal A, Samanek M, Paul T. Lung function in children and adolescents: methods, reference values. In: Zapletal A, editor. Progress in respiration research, Vol. 22. Basel: Karger; 1987:114-118.

21. Kraemer R, Blum A, Schilber A, Ammann R, Gallati S. Ventilation inhomogeneities in relation to standard lung function in patients with cystic fibrosis. Am J Respir Crit Care Med 2005;171(4):371-378.

22. Beardsmore C. Lung function from infancy to school age in cystic fibrosis. Arch Dis Child 1995;73:519-523.

23. Nikolaizik WH, Knopfli B, Leister E, de Boer P, Sievers B, Schoni $\mathrm{MH}$. The anaerobic threshold in cystic fibrosis: comparison of Vslope method, lactate turn points, and Conconi test. Pediatr Pulmonol 1998;25(3):147-153.

24. Gibson GJ. Pulmonary hyperinflation a clinical overview. Eur Respir J 1996;9(6):2640-2649.

25. Alison JA, Regnis JA, Donnelly PM, Adams RD, Sullivan CE, Bye PT. End-expiratory lung volume during arm and leg exercise in normal subjects and patients with cystic fibrosis. Am J Respir Crit Care Med 1998;158(5):1450-1456.

26. De Troyer A. Effect of hyperinflation on the diaphragm. Eur Respir J 1997;10(3):708-713.

27. Vogiatzis I, Georgiadou O, Golemati S, Aliverti A, Kosmas E, Kastanakis E, et al. Patterns of dynamic hyperinflation during exercise and recovery in patients with severe chronic obstructive pulmonary disease. Thorax 2005;60(9):723-729.

28. Wilkens H, Weingard B, Lo Mauro A, Schena E, Pedotti A, Sybrecht $\mathrm{GW}$, Aliverti A. Breathing pattern and chest wall volumes during exercise in patients with cystic fibrosis, pulmonary fibrosis and COPD before and after lung transplantation. Thorax 2010;65(9):808-814.

29. Caviedes IR, Delgado I, Soto R. Ventilatory inefficiency as a limiting factor for exercise in patients with COPD. Respir Care 2012; 57(4):583-589.

30. Godfrey S, Mearns M. Pulmonary function and response to exercise in cystic fibrosis. Arch Dis Child 1971;46(246):144-151.

31. Wasserman K, Hansen J, Sue D, Stringer W, Whipp B. Pathophysiology of disorders limiting exercise. In: Principles of exercise testing and interpretation. Philadelphia: Lippincott Williams \& Wilkins; 2005:120-123.

32. Moorcroft AJ, Dodd ME, Morris J, Webb AK. Symptoms, lactate and exercise limitation at peak cycle ergometry in adults with cystic fibrosis. Eur Respir J 2005;25(6):1050-1056.

33. Klijn PH, van der Net, Kimpen JL, Helders PJ, van der Ent CK. Longitudinal determinants of peak aerobic performance in children with cystic fibrosis. Chest 2003;124(6):2215-2219.

34. Gruet M, Brisswalter J, Mely L, Vallier JM. Clinical utility of the oxygen uptake efficiency slope in cystic fibrosis patients. J Cyst Fibros 2010;9(5):307-313.

35. Elphick HE, Mallory G. Oxygen therapy for cystic fibrosis. Cochrane Database Syst Rev 2009;(1):CD003884. DOI: 10.1002/14651858. CD003884.pub3.

36. Urguhart DS, Mongomery H, Jaffe A. Assessment of hypoxia in children with cystic fibrosis. Arch Dis Child 2005;90(11):1138-1143. 